\title{
X-ray Therapy
}

National Cancer Institute

\section{Source}

National Cancer Institute. X-ray Therapy. NCI Thesaurus. Code C93338.

A form of radiation therapy that uses high-energy radiation from $\mathrm{x}$-rays to kill cancer cells and shrink tumors. 